\title{
Can organic and transgenic soy be used as a substitute for animal protein by rats?
}

\section{L.L. Soares ${ }^{1}$, \\ A.M.M. Lucas ${ }^{1}$ and \\ G.T. Boaventura ${ }^{2}$}

\author{
${ }^{1}$ Curso de Ciências Médicas, Faculdade de Medicina, \\ 2Departamento de Nutrição e Dietética, Faculdade de Nutrição, \\ Universidade Federal Fluminense, Niterói, RJ, Brasil
}

\author{
Correspondence \\ L.L. Soares \\ Rua Pereira Nunes, 124/401 \\ 24210-430 Niterói, RJ \\ Brasil \\ E-mail: lavyleal@bol.com.br or \\ lavyleal@zipmail.com.br
}

Received April 16, 2004 Accepted February 11, 2005

\begin{abstract}
We evaluated the protein quality of organic and transgenic soy fed to rats throughout life. Thirty female Wistar rats were divided into three groups $(\mathrm{N}=10)$ : organic soy group (OSG) receiving organic soybased diet, genetically modified soy group (GMSG) receiving transgenic soy-based diet, and a control group (CG) receiving casein-based diet. All animals received water and isocaloric diet (10\% protein), ad libitum for 291 days. After this, the weight of GMSG animals (290.9 $\pm 9.1 \mathrm{~g})$ was significantly lower $(\mathrm{P} \leq 0.04)$ than $\mathrm{CG}(323.2 \pm 7.9 \mathrm{~g})$. The weight of OSG $(302.2 \pm 8.7 \mathrm{~g})$ was between that of the GMSG and the CG. Protein intake was similar for OSG $(308.4 \pm 6.8 \mathrm{~g})$ and GMSG $(301.5 \pm 2.5 \mathrm{~g})$, and significantly lower $(\mathrm{P} \leq 0.0005)$ than the CG $(358.4 \pm 8.1 \mathrm{~g})$. Growth rate was similar for all groups: OSG $(0.80 \pm$ $0.02 \mathrm{~g})$, GMSG $(0.81 \pm 0.03 \mathrm{~g})$ and CG $(0.75 \pm 0.02 \mathrm{~g})$. In addition to providing a good protein intake and inducing less weight gain, both types of soy were utilized in a manner similar to that of casein, suggesting that the protein quality of soy is similar to that of the standard protein casein. The groups fed soy-based diet gained less weight, which may be considered to be beneficial for health. We conclude that organic and transgenic soy can be fed throughout life to rats in place of animal protein, because contain high quality protein and do not cause a marked increase in body weight.
\end{abstract}

Key words - Soybean

- Transgenic soybean

- Protein

- Growth
Soy (Glycine Max (L.) Merril) is an important plant for human and animal nutrition, as well as for industrial purposes. Approximately $60 \%$ of all the processed food products contain ingredients derived from soy. Soy contains large amounts of protein despite its deficiency of sulfur-containing amino acids such as methionine and cystine. Its grain contains approximately $38 \%$ protein, $18 \%$ oil, $30 \%$ carbohydrates, $14 \%$ moisture, ash, and secondary components. It is also an important source of various minerals (Fe, $\mathrm{Zn}, \mathrm{Mg}, \mathrm{K}, \mathrm{Ca}, \mathrm{Mn}$, and $\mathrm{Se}$ ), vitamins (A, B1, B2, B6, and folic acid), phytoestrogens, and fiber (1). Although rich in protein, soy contains antinutritional factors commonly found in plants which reduce the bioavailability of the proteins ingested by the organism (2). Of these, the most important and most extensively studied are the protease inhibitors, which inhibit the proteolytic enzymes and consequently reduce the diges- 
tion of foods (3). Antinutritional factors can be minimized but not completely eliminated by heat treatment. In general, commercial soy products are submitted to heat treatment, so that they present $20 \%$ less trypsin inhibitory activity than raw soy (4). Today there is a tendency to use soy in substitution of animal protein, as traditionally done in countries like Japan and China.

Because of the increased soy consumption, transgenic soy has been created by genetic engineering. This is a genetically modified organism to which three foreign genes were added, one of them from a virus and the others from a bacterium found in soil. The advantage of this modification is that the plant becomes resistant to glyphosate herbicides used to destroy weeds, which end up by being harmful to the crop itself. With the genetic modification, this problem does not occur, with consequent increased production and reduced costs (5). However, some studies report that this modification could cause toxicity or allergic reactions, resistance to antibiotics and risks to the environment (6). There are still many doubts about the possible risks of transgenic soy regarding consumption and the environment and more studies are necessary to elucidate such questions. Organic soy is grown in an ecological manner without chemical products, and does not pollute the soil, does not contaminate the producer nor does it modify the product. This process, however, implies a significant loss of productivity and profit (7).

Animal protein is considered to be complete because it contains all 22 amino acids needed to maintain the human body. However, soy protein, although not as complete as the protein of animal origin, probably due to the antinutrients, is the plant protein of highest quality. Moreover, it has a preventive and/or therapeutic action on a series of diseases, being known as a functional food. This term is applied to foods or ingredients which, besides having basic nutritional functions, produce metabolic and/or physiologi- cal effects which are beneficial to health, when consumed as part of the usual diet, being safe for consumption without the need for medical supervision $(8,9)$. For example, it may promote protection from chronic diseases of aging, involve antioxidant activities, mitochondrial stabilizing functions, and other effects (10).

In addition to its high nutritional value, among all plants soy has the highest content of isoflavones, compounds that are closely similar in structure to estrogen, suggesting that it could exert similar activities. (11).

Not only is soy a food without a low fat content, but it also contains a large amount of fiber which helps control body weight and is considered to be beneficial for health (12).

The objective of the present study was to determine the ability of organic and transgenic soy to replace animal protein throughout life in rats, and their effects on the growth and maintenance of body weight.

The biological assay was conducted on 30 female Wistar rats aged 21 days (after lactation) at the beginning of the experiment from the Laboratory of Experimental Nutrition (LABNE) of the Department of Nutrition and Dietetics, Nutrition College, Fluminense Federal University, Niterói, RJ, Brazil. The rats were divided into three groups of ten animals each, which received the experimental diets for 291 days, as follows: control group (CG) fed a casein-based diet, organic soy group (OSG) fed an organic soybased diet supplemented with $0.3 \mathrm{~g}$ cysteine, and a genetically modified soy group (GMSG) receiving a transgenic soy-based diet. All animals were fed the above diets exclusively, and were the offspring of parents (preceding generation) who also received the same diet. The rats were kept in polypropylene cages, in an environment with controlled temperature at $22^{\circ} \mathrm{C}$ and a 12-h light/ dark period. Water and diets were offered $a d$ libitum, and food consumption and animal weight were recorded daily.

Transgenic soy was supplied by Jasmine 
Integral Foods (Curitiba, PR, Brazil) and organic soy was supplied by Bunge Foods (Porto Alegre, RS, Brazil). The suppliers of the other components of the diets were: Maizena starch by Refinements of Maize Ltda. (Granhuns, Recife, PE, Brazil), refined sugar by União (Rio de Janeiro, RJ, Brazil), Liza soil oil by Cargill Agricultural Ltda. (Mairinque, SP, Brazil), Microcel cellulose by Blanver Ltda. (Cotia, SP, Brazil), and cysteine, choline bitartrate, casein, and mixtures of vitamins and minerals by Rhoster Commerce and Industry Ltda. (Vargem Grande Paulista, SP, Brazil).

The soybeans used for the preparation of flour were manually selected, weighed on a Toledo digital scale (São Paulo, SP, Brazil) with $0.1 \mathrm{~g}$ accuracy and dried in a ventilated Fabbe-Prima (São Paulo, SP, Brazil) stove at $60^{\circ} \mathrm{C}$ for $30 \mathrm{~min}$. Boiling water was then added to the grains for $3 \mathrm{~min}$ and discarded, to permit husk removal under running water. The grains were then left in water for $4 \mathrm{~h}$ and the water was discarded. The soybeans were cooked in water for $30 \mathrm{~min}$, the water was discarded again, and the beans were placed in an oven for $12 \mathrm{~h}$ at $60^{\circ} \mathrm{C}$. After this procedure, the beans were ground and the flour obtained was used as the protein source for diet preparation.

All diets were prepared in the LABNE and contained $10 \%$ protein $(1.75 \%$ nitrogen $)$ and $363.95 \mathrm{kcal}$ per $100 \mathrm{~g}$, added to the mixtures of vitamins and minerals according to the rules of the Committee on Laboratory Animal Diets, 1979, modified according to the recommendations of the American Institute of Nutrition-93 (13). The ingredients of the diets (Table 1) were homogenized in a industrial mixer with boiling water. The mass obtained was transformed into tablets, which were dried in a ventilated oven at $60^{\circ} \mathrm{C}$ for 24 $\mathrm{h}$, properly identified and stored under refrigeration until the time for use.

We used the growth rate (GR) as a criterion for protein quality. Assuming that variations in total body protein occur due to dif- ferences in the protein quality of the diets, it is common to measure the variation of body weight as a global indicator of the ingested protein's performance. This rate is accepted by the majority of nutritionists as a valid method and is defined as GR = weight variation/protein intake (14).

Data are reported as means \pm SD and the results were analyzed statistically by multiple comparison one-way analysis of variance, with the level of significance set at $\mathrm{P} \leq$ 0.05 . When a statistically significant difference was detected between variables, the Scheffé test was applied using the Bonferroni coefficient for multiple comparisons. All statistical analyses were performed using the Stratigraphics Software plus 6.0.

At the end of 291 days of assay (rats aged 312 days), the mean weight of the group receiving soy-based diets was lower, with OSG (302.2 $\pm 7.9 \mathrm{~g})$ being similar to GMSG $(290.9 \pm 9.1 \mathrm{~g})$, while the mean weight of the CG was significantly $(\mathrm{P}<0.04)$ higher $(323.2$ $\pm 7.9 \mathrm{~g}$ ). Although the OSG was numerically inferior to the $C G$, the difference between the two groups was not significant. The protein intake of OSG (308.4 $\pm 6.8 \mathrm{~g})$ was similar to that of GMSG $(301.5 \pm 2.5 \mathrm{~g})$, and significantly lower $(\mathrm{P}<0.0005)$ than that of CG $(358.4 \pm 8.1 \mathrm{~g})$. Analysis of GR showed that this parameter was statistically similar in all groups, i.e., $0.80 \pm 0.02 \mathrm{~g}$ for $\mathrm{OSG}$, $0.81 \pm 0.03 \mathrm{~g}$ for GMSG, and $0.75 \pm 0.02 \mathrm{~g}$ for the CG (Table 2). Consequently, the GR

Table 1. Composition of the diets used for the assay.

\begin{tabular}{lrrr}
\hline Food (100 g) & Casein $(\mathrm{g})$ & Organic soy $(\mathrm{g})$ & Transgenic soy $(\mathrm{g})$ \\
\hline Protein & 11.54 & 20.96 & 20.28 \\
Starch & 61.41 & 57.23 & 58.04 \\
Refined sugar & 10.00 & 10.00 & 10.00 \\
Mineral mix & 3.50 & 3.50 & 3.50 \\
Vitamin mix & 1.00 & 1.00 & 1.00 \\
Soy oil & 7.00 & 2.81 & 2.94 \\
Cellulose & 5.00 & 3.95 & 3.99 \\
Choline bitartrate & 0.25 & 0.25 & 0.25 \\
Cysteine & 0.30 & 0.30 & 0.00 \\
Total & 100.00 & 100.00 & 100.00
\end{tabular}


of the groups that received the experimental diets was similar to the GR of the control group, which received a diet based on animal protein of high biological value. On this basis, we conclude that soy protein may have a better performance during the maintenance stage compared to casein, since the GR of CG was similar to that of the other groups despite the higher protein intake by the ani-

Table 2. Weight, protein intake and growth rate of 291-day-old animals.

\begin{tabular}{lccc}
\hline Group & Weight at 291 days $(g)$ & Protein intake $(g)$ & Growth rate $(g /$ day) \\
\hline CG & $323.2 \pm 7.9^{\mathrm{a}}$ & $358.4 \pm 8.1^{\mathrm{a}}$ & $0.75 \pm 0.02^{\mathrm{a}}$ \\
OSG & $302.2 \pm 8.7^{\mathrm{a}, \mathrm{b}}$ & $308.4 \pm 6.8^{\mathrm{b}}$ & $0.80 \pm 0.02^{\mathrm{a}}$ \\
GMSG & $290.0 \pm 9.1^{\mathrm{b}}$ & $301.5 \pm 2.5^{\mathrm{b}}$ & $0.81 \pm 0.03^{\mathrm{a}}$
\end{tabular}

$\mathrm{CG}=$ control group fed a casein-based diet; $\mathrm{OSG}=$ organic soy group fed an organic diet supplemented with $0.3 \mathrm{~g}$ cysteine; GMSG = genetically modified soy group receiving a transgenic soy-based diet.

Numbers followed by different superscript letter are statistically significant $(P \leq 0.05$, ANOVA followed by Scheffé and Bonferroni tests). mals. Furthermore, even though the groups fed the soy-based diet consumed smaller amounts of protein, they utilized it more efficiently.

It is known that soy is rich in antinutritional factors which reduce the bioavailability of foods. However, in the present experiment it was observed that these antinutrients do not alter the protein quality of soy, which can be used as an alternative to animal protein. The transgenic soy and organic soy had similar GR.

The present results show that the lifelong use of soy promoted a GR similar to that of the casein group, indicating that soy is an effective food with high protein quality, which can be used in substitution of animal protein by rats. Since a large amount of protein is not necessary during adulthood, soy is also recommended because it does not cause a marked increase in body weight.

\section{References}

1. Anderson JW, Johnstone BM \& Cook-Newell ME (1995). Metaanalysis of the effects of soy protein intake on serum lipids. New England Journal of Medicine, 333: 276-282.

2. Moughan PJ (2003). Amino acid availability: aspects of chemical analysis and bioassay methodology. Nutrition Research Reviews, 16: 127-141.

3. Miura EMY, Binotti MAR, Camargo DS, Mizubutti IY \& Ida El (2001). Avaliação biológica da soja com baixas atividades de inibidores de tripsina e ausência do inibidor Kunitz. Archivos Latinoamericanos de Nutrición, 51: 195-198.

4. Monteiro MRP, Moreira MA, Costa NMB, Oliveira MG \& Pires CV (2003). Avaliação da digestibilidade protéica de genótipos de soja com ausência e presença do inibidor de tripsina Kunitz e lipoxigenases. Brazilian Journal of Food Technology, 6: 99-107.

5. Rott ME, Lawrence TS, Wall EM \& Green MJ (2004). Detection and quantification of roundup ready soy in foods by conventional and real-time polymerase chain reaction. Journal of Agricultural and Food Chemistry, 52: 5223-5232.

6. Lack G (2002). Clinical risk assessment of GM foods. Toxicology Letters, 127: 337-340.

7. Magkos F, Arvaniti F \& Zampelas A (2003). Putting the safety of organic food into perspective. Nutrition Research Reviews, 16: 241252.
8. Pelletier S, Kundrat S \& Hasler CM (2002). Effects of an educational program on intent to consume functional foods. Journal of the American Dietetic Association, 102: 1297-1300.

9. Araújo W \& Araújo R (1999). Alimentos funcionais. Revista Brasileira de Nutrição Clínica, 14: 237-246.

10. Ferrari CK (2004). Functional foods, herbs and nutraceuticals: toward biochemical mechanisms of healthy aging. Biogerontology, 5 : 275-290.

11. Lissin LW \& Cooke JP (2000). Phytoestrogens and cardiovascular health. Journal of the American College of Cardiology, 35: 14031410.

12. Allison DB, Gadbury G, Schwartz LG, Murugesan R, Kraker JL, Henshka S, Fontaine KR \& Heymsfield SB (2003). A novel soybased meal replacement formula for weight loss among obese individuals: a randomized controlled clinical trial. European Journal of Clinical Nutrition, 57: 514-522.

13. Reeves PG, Nielsen FH \& Fahey Jr GCF (1993). AIN-93 purified diet of laboratory rodents: final report of the American Institute of Nutrition ad hoc Writing Committee on the Reformulation of the AIN-76A rodents diet. Journal of Nutrition, 123: 1939-1951.

14. Angelis RC (1995). Valor nutricional das proteínas: métodos de avaliação. Cadernos de Nutrição, 10: 8-29. 